\title{
POTENSI TAUCO SEBAGAI PANGAN FUNGSIONAL
}

\section{POTENCY OF TAUCO AS FUNCTIONAL FOOD}

\author{
Sadiah Djayasupena, Giana Suci Korinna, Saadah Diana Rachman \& Uji Pratomo \\ Departemen Kimia, FakultasMatematika dan Ilmu Pengetahuan Alam, UniversitasPadjadjaran, \\ Jl. Raya Bandung-Sumedang km. 21 Jatinangor, Sumedang, Jawa Barat 45363 \\ *Alamat Korespondensi: sadiah@unpad.ac.id
}

\begin{abstract}
Abstrak: Kesadaran akan besarnya hubungan antara makanan dan kemungkinan timbulnya penyakit, telah mengubah pandangan bahwa makanan bukan sekedar untuk mengenyangkan, tetapi juga untuk kesehatan. Makanan hasil fermentasi yang bahan baku utamanya kedelai cukup banyak di Indonesia dan salah satu pengolahan kedelai melalui proses fermentasi adalah produk yang dikenal sebagai tauco. Tauco tidak digunakan secara langsung, tetapi sebagai bumbu ataupun sebagai penyedap rasa. Tujuan dari penelitian adalah untuk menganalisis kadar nutrisi dan menguji aktivitas antioksidan yang terkandung dalam tauco. Tahap-tahap yang dilakukan dalam penelitian ini, diantaranya proses pembuatan tauco, penentuan kadar nutrisi pada tauco, meliputi kadar protein dengan metode Kjeldahl, kadar lemak dengan metode Soxhlet, kadar air dengan metode Gravimetri, kadar abu dengan metode Gravimetri, kadar karbohidrat dengan metode by difference dan pengujian aktivitas antioksidan dengan metode DPPH. Tauco dengan kadar protein dan lemak yang terbaik terdapat pada perlakuan larutan garam natrium klorida $20 \%$ (b/v) berturut-turut sebesar 33,19 dan 18,37\%. Aktivitas antioksidan yang tinggi dalam menginhibisi radikal bebas yaitu dengan nilai $\mathrm{IC}_{50} 2,96 \mathrm{ppm}$ pada fraksi air yang terdapat dalam tauco larutan garam natrium klorida $10 \%$. Dengan kandungan gizi yang tinggi, tauco berpotensi sebagai pangan fungsional.
\end{abstract}

Kata kunci: Tauco, pangan fungsional, fermentasi, Kjehdal, dan Soxhlet

\begin{abstract}
Awareness of the magnitude of the relationship between food and the possibility of disease has changed the view that food is not just for filling, but also for health. Fermented food are the main raw material of soy is quiet a lot in Indonesia and one of soybean processing via fermentation process is the product known as tauco. Tauco not used directly, but as a condiment are as a flavoring. The aim of this research is to analyze and test the activity levels of antioxidant nutrients containing in tauco. The steps are the process of making tauco, determining the levels of nutrients in tauco, including protein content by Kjeldahl method, fatty content by Soxhlet method, the water content by gravimetric method, ash content by gravimetric method, carbohydrates content by difference method and the method by testing antioxidant activity by DPPH method. Tauco with the best levels of the protein dan fat contained in sodium chloride solution $20 \%(w / v)$ consecutively are $33.19 \%$ and $18.37 \%$. High antioxidant activity in inhibit free radicals of $I C_{50}$ value of $2.96 \mathrm{ppm}$ in fraction of water contained in tauco 10\% salt solution. Tauco is very potential as food functional because have the high level of nutrients.
\end{abstract}

Keywords: Tauco, food functional, fermentation, Kjehdal, and Soxhlet

\section{PENDAHULUAN}

Menurut BPOM (2001), pangan fungsional adalah pangan yang secara alami maupun melalui proses, mengandung satu atau lebih senyawa yang berdasarkan hasil kajian ilmiah dianggap mempunyai fungsi-fungsi fisiologis tertentu yang bermanfaat bagi kesehatan.

Salah satu cara pengolahan pangan adalah fermentasi. Fermentasi telah lama digunakan dan merupakan salah satu cara pemrosesan dan bentuk pengawetan makanan tertua (Achi, 2005). Fermentasi merupakan cara untuk memproduksi berbagai produk yang menggunakan biakan mikroba melalui aktivitas metabolisme baik secara aerob maupun anaerob. Fermentasi dapat terjadi karena adanya aktivitas mikroba pada substrat organik yang sesuai. Terjadinya fermentasi dapat menyebabkan perubahan sifat bahan pangan akibat pemecahan kandungan bahan pangan tersebut sehingga memungkinkan makanan lebih bergizi, lebih mudah dicerna, lebih aman, dapat memberikan rasa yang lebih baik dan memberikan tekstur tertentu pada produk pangan. Fermentasi juga merupakan suatu cara yang efektif dengan biaya rendah untuk mengawetkan, menjaga kualitas dan keamanan makanan (Misgiyarta \& Widowati, 2003).

Makanan hasil fermentasi yang bahan baku utamanya kedelai cukup banyak di Indonesia dan salah satu pengolahan kedelai melalui proses fermentasi adalah produk yang dikenal sebagai tauco. Tauco bagi kalangan tertentu merupakan produk yang tidak dapat dipisahkan dari menu makanan sehari-hari. Kandungan protein tauco cukup tinggi, tetapi tauco tidak dapat digunakan sebagai sumber protein dalam makanan (Suwaryono \& Ismeini, 1988). Tauco tidak digunakan secara langsung, tetapi 
sebagai bumbu ataupun sebagai penyedap rasa. Pada proses pembuatan tauco digunakan larutan garam natrium klorida dengan variasi larutan garam maksimal 20\% seperti yang digunakan pada produk tauco di pasaran (Indriani, 1990). Garam dipergunakan manusia sebagai salah satu metode pengawetan pangan yang pertama dan masih dipergunakan secara luas untuk mengawetkan berbagai macam makanan. Garam akan berperan sebagai penghambat selektif pada mikroorganisme pencemar tertentu.

Pada penelitian ini dilakukan pembuatan tauco dengan variasi larutan garam natrium klorida dan analisis gizinya serta aktivitas antioksannya.

\section{BAHAN DAN METODE}

\section{Bahan dan Alat Penelitian}

Bahan yang digunakan pada penelitian ini adalah air, garam natrium klorida sebanyak 5, 10, 15, dan $20 \mathrm{~g}$, kapang $R$. oligosporus berbentuk ekstrak sebanyak $6 \mathrm{~g}$ yang diperoleh dari KOPTI (Koperasi Tahu Tempe Indonesia), dan kedelai sebanyak $1 \mathrm{~kg}$ yang diperoleh dari KOPTI.

Bahan-bahan kimia yang digunakan adalah akuades, alkohol, asam klorida $0,1 \mathrm{~N}$, asam sulfat, etilasetat, indikator Toshiro, katalis (campuran tembaga sulfat dan kalium sulfat), metanol, natrium hidroksida $30 \%$, dan $n$-heksana.

Peralatan yang digunakan pada penelitian ini antara lain adalah alat ekstraksi Soxhlet, labu Kjeldahl, oven, desikator, blender, spektrofotometer UV-visible, neraca analitis dan peralatan gelas lain yang biasa digunakan di laboratorium.

\section{Pembuatan Tauco}

Kacang kedelai mula-mula dibersihkan dari kotoran dan benda asing lainnya, lalu dicuci sampai bersih. Kemudian dilakukan perendaman kedelai selama 1x24 jam, dan keesokan harinya kedelai dikupas kulitnya secara manual. Pengupasan kulit kedelai dapat juga dilakukan dengan alat pengupasan dalam keadaan kering, kemudian kedelai yang telah dikupas kulitnya direndam dalam air.

Setelah direbus, ditiriskan dan didinginkan, kedelai dicampur dengan ragi, kemudian ditebarkan di atas tampah dan ditutup. Kondisi seperti ini memungkinkan substrat ditumbuhi dan difermentasi oleh kapang secara spontan, karena kapang (sporanya) sudah terdapat pada permukaan tampah dan lingkungan sekitarnya. Pada umumnya fermentasi dilakukan pada suhu ruang selama 2 hari.

Hasil fermentasi kapang dijemur dan gumpalan biji kedelai yang terbentuk dihancurkan, dan kemudian direndam dalam larutan garam natrium klorida dengan variasi 5, 10, 15, dan $20 \%$ (b/v) selama 2 malam. Perendaman dilakukan dalam wadah bertutup, dan dilakukan di tempat terbuka (agar dapat terjemur sinar matahari). Hasil fermentasi dalam larutan garam disebut dengan tauco mentah (Muchtadi, 2010).

\section{Penentuan kadar protein tauco dengan metode Kjeldahl}

Tauco dihaluskan, dan dikeringkan, kemudian ditimbang sebanyak $0,5 \mathrm{~g}$ dan dimasukkan ke dalam labu Kjeldahl. Setelah itu ke dalamnya ditambahkan dengan asam sulfat sebanyak $10 \mathrm{~mL}$ dankatalis (campuran tembaga sulfat dan kalium sulfat $=1: 8$ ) sebanyak 2 g. Kemudian dilakukan dekstruksi dalam lemari asam sampai cairan berwarna hijau jernih. Hasil destruksi dimasukkan ke dalam labu ukur 100 $\mathrm{mL}$ dan ditambahkan air suling sampai batas $100 \mathrm{~mL}$. Larutan hasil dekstruksi dipipet $10 \mathrm{~mL}$ dan dimasukkan ke dalam alat destilasi Kjeldahl. Kemudian ke dalamnya ditambahkan $10 \mathrm{~mL}$ natrium hidroksida $30 \%$ dan didistilasi selama \pm 30 menit. Labu erlenmeyer yang digunakan untuk menampung destilat, diisi terlebih dahulu dengan larutan asam klorida $0,1 \mathrm{~N}$ sebanyak $25 \mathrm{~mL}$ dan indikator Toshiro sebanyak dua tetes. Kelebihan asam klorida selanjutnya dititrasi dengan natrium hidroksida $0,1 \mathrm{~N}$. Untuk menghitung kandungan nitrogen totalnya dapat menggunakan rumus:

$$
\text { Kandungan } \mathrm{N}=\frac{(\mathrm{Va} \mathrm{Na}-\mathrm{Vb} \mathrm{Nb}) \times 14 \times 100 / 10}{\text { berat sampel }} \times 100 \%
$$

Kadar protein $=$ kandungan $\mathrm{N}$ total $\mathrm{x} 5,75$

$$
\text { Keterangan: } \begin{array}{ll}
\mathrm{VaNa} & =\text { mg ekivalenasam } \\
\mathrm{VbNb} & =\mathrm{mg} \text { ekivalenbasa } \\
100 / 10 & =\text { faktorpengenceran } \\
5,75 & =\text { factor konversi untuk bahan } \\
& \text { pangan hayati }
\end{array}
$$

(Apriyantono dkk., 1989).

\section{Penentuan kadar lemak dengan metode Soxhlet}

Tauco yang akan diekstraksi ditimbang sebanyak $3 \mathrm{~g}$, lalu dimasukkan ke dalam kantong yang dibuat dari kertas saring dan ditutup dengan kapas bebas lemak. Kemudian dimasukkan ke dalam alat Soxhlet. Setelah itu dipasang labu dan kondensor. Tauco diekstrak dengan 30-40 mL nheksana (titik didih $60-70^{\circ} \mathrm{C}$ ) di atas penangas air sampai n-heksana sudah kelihatan jernih, ekstraksi dilakukan selama \pm 4 jam. Selanjutnya labu yang berisi residu (lemak) diuapkan dan dikeringkan dalam oven $105-110^{\circ} \mathrm{C}$ selama 1 jam. Kemudian didinginkan di dalam desikator dan ditimbang sampai diperoleh berat yang tetap. Kadar lemak dihitung berdasarkan rumus:

$$
\text { Kadar lemak }=\frac{(B-A)}{\text { bobot sampel }} \times 100 \%
$$

Keterangan: $\quad \mathrm{A}=$ Berat labu kosong $(\mathrm{g})$

$$
\mathrm{B}=\text { Berat labu dan residu minyak }(\mathrm{g})
$$

(Apriyantono dkk, 1989)

\section{Penentuan kadar air dengan metode oven}

Sebanyak 2 g sampel yang telah dihancurkan, ditimbang dengan segera menggunakan cawan 
tertutup yang terlebih dahulu telah ditetapkan bobotnya. Cawan beserta isinya ditempatkan di dalam oven pada suhu $105 \pm 2^{\circ} \mathrm{C}$ (cawan dalam keadaan terbuka) selama 4 jam. Setelah 4 jam, cawan ditutup menggunakan penutupnya dan dikeluarkan dengan segera untuk dimasukkan ke dalam desikator. Setelah cawan mencapai suhu kamar, lalu ditimbang beserta isinya. Kadar air dihitung dengan rumus:

$$
\text { Kadar air }=\frac{(M 1-M 2)}{(M 1-M 0)} \times 100 \%
$$

Keterangan:

M0 = Bobot cawan dan tutupnya $(\mathrm{g})$

M1 = Bobot cawandan contoh uji sebelum pengeringan (g)

M2 = Bobot cawandan contoh uji setelah pengeringan (g)

(Apriyantono dkk,1989)

\section{Penentuan kadar abu dengan metode oven}

Cawan kosong dikeringkan dalam oven selama 15 menit dan didinginkan dalam desikator, kemudian ditimbang. Sebanyak $2 \mathrm{~g}$ tauco yang telah dihaluskan ditimbang dalam cawan. Cawan beserta isinya dimasukkan ke dalam tanur suhu $600^{\circ} \mathrm{C}$. Cawan dipindahkan ke desikator kemudian didinginkan. Labu ditimbang sampai diperoleh berat yang tetap. Kadar abu dihitung dengan rumus:

Bobot $\mathrm{abu}=($ Bobot cawan $+\mathrm{abu})-$ bobot cawan

$$
\text { Kadar abu }=\frac{\text { bobot } a b u}{\text { bobot contoh }} \times 100 \%
$$

(Apriyantono dkk,1989)

\section{Penentuan kadar karbohidrat dengan metode by difference}

Kadar karbohidrat diperoleh dengan menggunakan metode by difference, yaitu dengan mengurangi total kadar seluruh komponen (100\%) oleh total kadar protein, lemak, air yang telah diperoleh. Kadar karbohidrat dihitung dengan rumus:

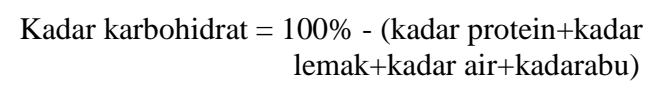

(Apriyantono dkk,1989)

\section{Penentuan kadar antioksidan}

Sampel sebanyak $1 \mathrm{~kg}$ yang telah dihaluskan, dimaserasi dengan menggunakan pelarut metanol total sebanyak 3,5 L secara berulang-ulang yaitu $5 \times 24$ jam.

Maserat kemudian disaring untuk memisahkan ampas lalu dipekatkan menggunakan alat rotary evapotator pada tekanan yang rendah dan suhu $\pm 40^{\circ} \mathrm{C}$ sehingga diperoleh ekstrak pekat metanol. Ekstrak metanol sebanyak $5 \mathrm{~g}$ dilarutkan dalam $5 \mathrm{~mL}$ air dan dipartisi dalam corong pisah dengan menggunakan pelarut $n$-heksana sebanyak $15 \mathrm{~mL}$ (perbandingan air dan $n$-heksana 1:3) sehingga didapatkan fraksi $n$-heksana dan fraksi air. Fraksi air dipartisi kembali menggunakan etil asetat sebanyak $15 \mathrm{~mL}$ (perbandingan air dan etil asetat 1:3) sehingga diperoleh fraksi etil asetat dan fraksi air.

Tabung reaksi reference dan blanko selanjutnya diukur pada spektra sinar tampak dengan panjang gelombang $(\lambda)$ maksimum $516 \mathrm{~nm}$. Pengukuran dilakukan 30 menit setelah penambahan DPPH. Untuk pengukuran antiradikal bebas bahan uji digunakan metode yang sama, hanya saja pelarut diganti dengan larutan uji (senyawa aktif). Setelah itu dihitung nilai $\mathrm{IC}_{50}$ nya.

\section{HASIL DAN PEMBAHASAN}

Proses pembuatan tauco melalui dua tahap fermentasi. Pertama fermentasi dengan kapang R. oligosporus. Kedua fermentasi dalam larutan garam natrium klorida. Penambahan garam bertujuan sebagai pengawet dan pemberi cita rasa.

Kedelai yang digunakan pada proses ini sebanyak $1 \mathrm{~kg}$ dengan takaran kapang sebanyak $6 \mathrm{~g}$. Tauco yang dihasilkan dari proses ini berwarna cokelat muda untuk semua perlakuan. Produk tauco yang diperoleh ditunjukkan pada Gambar 1.
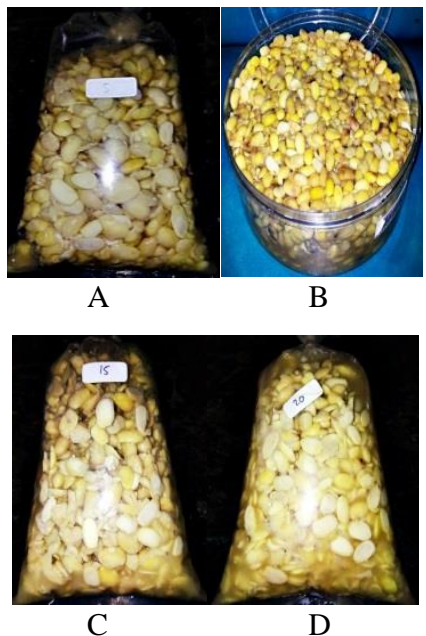

Gambar 1. Produk tauco menggunakan larutan garam 5\% (A), produk tauco menggunakan larutan garam $10 \%$ (B), produk tauco menggunakan larutan garam $15 \%(\mathrm{C})$, produk tauco menggunakan larutan garam $20 \%$ (D).

Tauco untuk setiap perlakuan diberikan variasi larutan garam natrium klorida 5, 10, 15, dan $20 \%$. Digunakan variasi tersebut bertujuan untuk mengontrol mikroorganisme, yaitu merangsang pertumbuhan mikroorganisme yang diinginkan berperan dalam fermentasi, dan menghambat pertumbuhan mikroorganisme pembusuk dan patogen. Variasi larutan garam natrium klorida yang digunakan berkisar antara 5-20\%. Larutan garam $20 \%$ merupakan larutan garam maksimal yang diberikan pada proses pembuatan tauco dan diaplikasikan pada produk-produk dipasaran. Larutan 
garam 5\% merupakan larutan garam minimal yang digunakan untuk dapat mengontrol mikroorganisme selama proses fermentasi.

Penentuan kadar protein dilakukan dengan metode Kjeldahl. Metode ini hanya menentukan kadar nitrogen total untuk mewakili kadar protein yang ada. Hasil analisis kadar protein tauco pada berbagai variasi konsentrasi larutan garam dapat dilihat pada Tabel 1. Berdasarkan hasil analisis kadar protein tauco menunjukkan bahwa kadar protein tauco dengan perlakuan variasi larutan garam 20\% memilki kadar protein tertinggi sebesar 33,19\% sedangkan yang terendah yaitu $30,74 \%$ pada larutan garam $5 \%$. Bila dibandingkan dengan kadar protein menurut standar Menkes $(10,4 \%)$, protein dalam tauco termasuk dalam jumlah yang sangat tinggi. Tingginya kandungan protein yang terdapat dalam tauco disebabkan oleh kapang $R$. Oligosporus yang menghasilkan enzim-enzim protease dalam jumlah yang banyak. Semakin baik pertumbuhan kapang, semakin tinggi pula kadar protein yang dihasilkan, hal ini disebabkan peningkatan aktivitas proteolitik kapang yang akan menguraikan protein menjadi asan-asam amino, sehingga nitrogen terlarutnya akan mengalami peningkatan, maka kadar protein yang dihasilkan akan menjadi lebih tinggi (Murata et al., 1967).

Tabel 1. Perbandingan kadar protein tauco hasil analisis dengan kadar protein tauco standar

\begin{tabular}{ccccc}
\hline \multicolumn{2}{c}{ Kadar protein hasil analisis (\%) } & $\begin{array}{c}\text { Kadar protein } \\
\text { menurut } \\
\text { 736a/Menkes/X } \\
\text { I/1989 }\end{array}$ \\
\hline A & B & C & D & Min. 10,4 \\
\hline
\end{tabular}

Ket: $A=$ Tauco larutan garam 5\%, B = Tauco larutan garam $10 \%, C=$ Tauco larutan garam $15 \%, D=$ Tauco larutan garam $20 \%$

Penentuan kadar lemak dilakukan dengan metode Soxhlet. Metode ini digunakan untuk mengekstraksi lemak bebas dengan pelarut non polar. Hasil analisis kadar lemak tauco diperlihatkan apda Tabel 2.

Tabel 2. Perbandingan kadar lemak tauco hasil analisis dengan kadar lemak tauco standar

\begin{tabular}{ccccc}
\hline \multicolumn{3}{l}{ Kadar lemak hasil analisis (\%) } & $\begin{array}{c}\text { Kadar lemak } \\
\text { menurut } \\
\text { 736a/Menkes/X } \\
\text { I/1989 }\end{array}$ \\
\cline { 1 - 3 } $\mathrm{A}$ & $\mathrm{B}$ & $\mathrm{C}$ & $\mathrm{D}$ & Maks. 20,9 \\
\hline 8,77 & 14,06 & 16,10 & 18,37 & M \\
\hline
\end{tabular}

Ket: $A=$ Tauco larutan garam 5\%, B = Tauco larutan garam $10 \%, C=$ Tauco larutan garam $15 \%, D=$ Tauco larutan garam $20 \%$

Berdasarkan hasil analisis kadar lemak tauco menunjukkan bahwa kadar lemak tauco dengan perlakuan variasi larutan garam $20 \%$ memilki kadar lemak tertinggi sebesar $18,37 \%$. Kapang tauco, $R$. oligosporus, memproduksi enzim lipase yang aktif selama proses fermentasi (Siswono, 2002). Dalam larutan garam, hasil penguraian enzim lipase digunakan kembali oleh kapang tauco sebagai sumber energi dan selanjutnya kapang tersebut tidak aktif atau mati. Enzim lipase ini memegang peranan penting dalam menguraikan lemak yang terdapat pada substrat menjadi gliserol dan asam lemak bebas, sehingga enzim ini berperan besar pada kandungan lemak dalam tauco.

Kestabilan optimum bahan makanan dapat tercapai jika kadar air bahan berkisar 3-8\%, karena pada keadaan tersebut bahan makanan tidak mudah terserang oleh ketengikan (oksidasi) dan lebih tahan terhadap serangan mikroorganisme seperti bakteri, kapang, dan khamir. Kadar air sangat berpengaruh terhadap mutu bahan pangan, dan hal ini merupakan salah satu sebab mengapa dalam pengolahan pangan air tersebut sering dikeluarkan atau dikurangi dengan cara penguapan atau pengentalan dan penegeringan.

Data hasil analisis kadar air sampel tauco disajikan pada Tabel 3. Data analisis menunjukkan bahwa keseleruhan kadar air sampel berada di bawah ambang batas maksimum yang diizinkan.

Tabel 3. Perbandingan kadar air tauco hasil analisis dengan kadar air tauco standar

\begin{tabular}{ccccc}
\hline \multicolumn{3}{c}{ Kadar air hasil analisis (\%) } & $\begin{array}{c}\text { Kadar air } \\
\text { menurut } \\
736 a / \text { Menkes/X } \\
\text { I/1989 }\end{array}$ \\
\cline { 1 - 4 } $\mathrm{A}$ & $\mathrm{B}$ & $\mathrm{C}$ & $\mathrm{D}$ & Maks. 64,4 \\
\hline 37,87 & 35,73 & 39,56 & 36,70 & . \\
\hline
\end{tabular}

Ket: $A=$ Tauco larutan garam 5\%, B = Tauco larutan garam $10 \%, C=$ Tauco larutan garam 15\%, D = Tauco larutan garam $20 \%$

Penentuan kadar abu dilakukan dengan metode oven. Pada proses pengabuan zat-zat organik diuraikan menjadi air dan kabon monoksida, tetapi bahan anorganik tidak. Analisis kadar abu dilakukan untuk mengetahui secara umum kandungan mineral yang terdapat dalam sampel. Kadar abu dari tauco untuk tiap perlakuan ditunjukkan pada Tabel 4. Nilai kadar abu terbesar diperoleh dari perlakuan larutan garam $20 \%$ sebesar $11,65 \%$. Hasil analisis menunjukkan bahwa dengan penambahan variasi larutan garam natrium klorida meningkatkan kadar abu tauco.

Tabel 4. Perbandingan kadar abu tauco hasil analisis dengan kadar abu tauco standar

\begin{tabular}{ccccc}
\hline \multicolumn{3}{c}{ Kadar abu hasil analisis (\%) } & $\begin{array}{c}\text { Kadar abu } \\
\text { menurut } \\
\text { 736a/Menkes/X } \\
\text { I/1989 }\end{array}$ \\
\hline A & B & C & D & Min. 9,2 \\
\hline 9,44 & 9,67 & 10,48 & 11,65 & \\
\hline
\end{tabular}

Ket: $A=$ Tauco larutan garam 5\%, B = Tauco larutan garam $10 \%, C=$ Tauco larutan garam 15\%, D = Tauco larutan garam $20 \%$ 
Penentuan kadar karbohidrat kedelai dilakukan dengan metode by difference. Perhitungan kadar karbohidrat kedelai dilakukan dengan mengurangi total komponen $100 \%$ oleh total kadar protein, lemak, air, dan abu. Kadar karbohidrat dari tauco untuk tiap perlakuan ditunjukkan pada Tabel 5.

Kadar karbohidrat hasil analisis terbesar adalah pada konsentrasi garam 5\% $(13,18 \%)$ dan yang paling terkecil adalah pada $20 \%(0,09 \%)$. Hal ini mungkin disebabkan oleh proses perendaman dalam larutan garam yang menyebabkan perubahan biokimia dengan adanya enzim endogenous, sehingga larutnya sebagian karbohidrat dalam air perendaman. Semakin banyak kapang yang tumbuh pada substrat maka kadar karbohidrat akan semakin menurun, karena kapang $R$. oligosporus akan mengeluarkan enzim-enzim yang dapat memecah karbohidrat menjadi glukosa yang selanjutnya akan digunakan sebagai sumber makanan bagi kapang tersebut. Oleh karena itu kadar karbohidrat berbanding terbalik dengan kadar protein dan lemak.

Tabel 5. Perbandingan kadar karbohidrat tauco hasil analisis dengan kadar karbohidrat tauco standar

\begin{tabular}{|c|c|c|c|c|}
\hline \multicolumn{4}{|c|}{ Kadar karbohidrat hasil analisis (\%) } & \multirow{2}{*}{$\begin{array}{c}\text { Kadar } \\
\text { karbohidrat } \\
\text { menurut } \\
\text { 736a/Menkes/X } \\
\text { I/1989 }\end{array}$} \\
\hline A & $\mathrm{B}$ & $\mathrm{C}$ & $\mathrm{D}$ & \\
\hline 13,18 & 8,98 & 1,48 & 0,09 & Maks. 24,1 \\
\hline
\end{tabular}

Ket: $A=$ Tauco larutan garam 5\%, B = Tauco larutan garam $10 \%, C=$ Tauco larutan garam $15 \%, D=$ Tauco larutan garam $20 \%$

Penentuan aktivitas antioksidan dengan metode DPPH terhadap sampel kedelai dan tauco dilakukan pada fraksi $n$-heksana, fraksi etil asetat, dan fraksi air yang didapatkan dari hasil partisi serta ekstrak metanol. Data hasil pengujian aktivitas antioksidan fraksi-fraksi dalam sampel kedelai dan tauco disajikan dalam Tabel 6.

Tabel 6. Nilai $\mathrm{IC}_{50}$ tiap-tiap fraksi dalam sampel kedelai dan tauco

\begin{tabular}{ccccc}
\hline \multirow{2}{*}{ Sampel } & \multicolumn{4}{c}{$\mathrm{IC}_{50}(\mathrm{ppm})$} \\
\cline { 2 - 5 } & $\mathrm{MeOH}$ & $n$-heksana & & \\
\cline { 2 - 5 } & 7,14 & 4,91 & 3,82 & 3,03 \\
Kedelai & 4,85 & 10,41 & 4,41 & 2,96 \\
$\begin{array}{c}\text { Tauco larutan garam } \\
\text { 10\% }\end{array}$ & 7,27 & 13,65 & 10,54 & 6,08 \\
$\begin{array}{c}\text { Tauco larutan garam } \\
\text { 15\% }\end{array}$ & & & & \\
$\begin{array}{c}\text { Tauco larutan garam } \\
\text { 20\% }\end{array}$ & 10,19 & 9,71 & 31,22 & 56,81 \\
\hline
\end{tabular}

Berdasarkan Tabel 6, dapat disimpulkan bahwa aktivitas antioksidan dari kedelai dan tauco untuk semua perlakuan memiliki nilai yang cukup tinggi, yaitu dilihat dari harga 50\% inhibisi atau 50\% nilai perendaman DPPH.
Semakin rendah nilai $\mathrm{IC}_{50}$ suatu bahan, maka semakin tinggi aktivitas antioksidannya. Hal tersebut disebabkan, karena hanya dibutuhkan sejumlah kecil konsentrasi sampel untuk meredam 50\% radikal bebas DPPH.

\section{KESIMPULAN}

1. Tauco yang mempunyai kualitas terbaik ditinjau berdasarkan larutan garam natrium klorida yang diberikan. Tauco dengan kadar protein dan lemak yang terbaik terdapat pada perlakuan larutan garam natrium klorida $20 \%(\mathrm{~b} / \mathrm{v})$ masing-masing sebesar 33,19 dan 18,37\%. Ini membuktikan bahwa adanya hubungan antara kadar gizi dengan potensi tauco sebagai pangan fungsional.

2. Aktivitas antioksidan yang tinggi dalam menginhibisi radikal bebas yaitu dengan nilai $\mathrm{IC}_{50}$ 2,96 ppm pada fraksi air yang terdapat dalam tauco larutan garam natrium klorida $10 \%$.

\section{DAFTAR PUSTAKA}

Achi, O.K. (2005). The potential for upgrading traditional fermented foods through biotechnology. African Journal of Biotechnology 4(5): 375-380.

Apriyantono, A., Fardiaz, D., Puspitasari, N. L., Sedarnawati \& Budianto, S. (1989). Petunjuk Laboratorium Analisis Pangan. Departemen Pendidikan dan Kebudayaan, Direktorat Jenderal Pendidikan Tinggi, Pusat Antar Universitas Pangan dan Gizi, Institut Pertanian Bogor. Bogor.

Badan Pengawasan Obat dan Makanan. (2001). Kajian Proses Standarisasi Produk Pangan Fungsional di Badan Pengawasan Obat dan Makanan. Lokakarya Kajian Penyusunan Standar Pangan Fungsional Badan Pengawasan Obat dan Makanan. Jakarta.

Indriani, E.A. (1990). Pengaruh Substitusi NaCI dengan KCI Terhadap Sifat Mikrobiologi, Kimiawi dan Sensori Tauco. Skripsi Jurusan PHP, Fakultas Teknologi Pertanian UGM, Yogyakarta.

Misgiyarta \& Widowati, S. (2003). Seleksi dan Karakterisasi Bakteri Asam Laktat (BAL) Indigenous. Di dalam : Prosiding Seminar Hasil Penelitian Rintisan dan Bioteknologi Tanaman.

Muchtadi, D. (2010). Kedelai Komponen Untuk Kesehatan, Alfabeta, Bandung.

Murata, K., Ikehata, H \& Miyamoto, T. (1967). Studies on vhe vutritional value of tempeh. Journal of Food Science.32: 5.

Siswono, J. (2002). Oncom Menutup Kekurangan Energi dan Protein, Gizinet, Jakarta.

Suwaryono, O \& Ismeini, Y. (1988). Fermentasi Bahan Makanan Tradisional, PAU Pangan dan Gizi UGM, Yogyakarta. 